\title{
Effect of recycled manure solids as bedding on bulk tank milk and implications for cheese microbiological quality
}

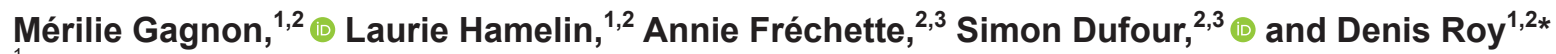 \\ ${ }^{1}$ Département des sciences des aliments, Laboratoire de génomique microbienne, Université Laval, 2440, boulevard Hochelaga, \\ Québec QC G1V 0A6, Canada \\ ${ }^{2}$ Regroupement de recherche pour un lait de qualité optimale (Op+Lait), 3200, rue Sicotte, Saint-Hyacinthe, QC J2S 2M2, Canada \\ ${ }^{3}$ Département de pathologie et microbiologie, Faculté de médecine vétérinaire, Université de Montréal, C. P. 5000, Saint-Hyacinthe, \\ QC J2S 7C6, Canada
}

\section{ABSTRACT}

The dairy farm environment influences the raw milk microbiota and consequently affects milk processing. Therefore, it is crucial to investigate farm management practices such as the bedding materials. The aim of this study was to evaluate the effect of recycled manure solids (RMS) as bedding material on bulk tank milk and microbiological implications for cheese quality. Bulk tank samples were collected from 84 dairy farms using RMS or straw bedding. The use of RMS did not influence thermophilic and mesophilic aerobic viable counts from spores. However, straw-milk samples gave higher values for mesophilic anaerobic spore-forming bacteria (0.44 log $\mathrm{cfu} / \mathrm{mL}$ ) than RMS-milk samples (0.17 log $\mathrm{cfu} / \mathrm{mL})$. The presence of thermoresistant lactic acid bacteria was not increased in milk from farms using RMS. Nevertheless, taxonomic profiles of thermoresistant bacteria isolated were different between the 2 types of milk. More Enterococcus faecalis and Streptococcus spp. were identified in RMS-milk samples. Thermoresistant enterococci and streptococci could easily end up in cheese. Therefore, milk proteolytic activities of these isolates were tested. Neither Streptococcus spp. nor Enterococcus faecium isolates exhibited proteolytic activities, whereas $53 \%$ of E. faecalis showed some. Also, only 1 vancomycin-resistant enterococcus was detected. Survival of selected RMS-milk samples isolates (3 E. faecalis and 1 Streptococcus thermophilus) was evaluated during a model Cheddar cheese manufacture. Although those strains survived well, they did not modify the acidification curve of milk. However, they might cause organoleptic defects during cheese maturing.

Received April 16, 2019

Accepted September 9, 2019.

*Corresponding author: denis.roy@fsaa.ulaval.ca
Key words: biobedding, spore-forming bacteria, vancomycin-resistant enterococci, Cheddar

\section{INTRODUCTION}

Dairy farm management undergoes change for practical and economic reasons or for food safety. Recently, bedding from recycled manure solids (RMS) has gained popularity in Canada. This practice is widespread in United Kingdom and has been used for several years (Bradley et al., 2014). Manure solids are separated from the liquid fraction using a screw, a roller press, or highperformance slurry separation equipment (Leach et al., 2015). Manure contains a high quantity of microorganisms that would be detrimental to animal health (e.g., Escherichia coli vs. mastitis). Therefore, the solid fraction is often composted to modify the bacterial population from that of manure. The bacterial fermentation raises the temperature during this process. Anaerobic digestion is used instead of or as well as composting, commonly in the United States (Leach et al., 2015). A lot of potential benefits are associated with RMS, such as cost savings, availability, and cow comfort (Bradley et al., 2014; Fournel et al., 2019b). Also, this type of bedding can be considered as a strategy to mitigate pollution from livestock manure management (Petersen et al., 2007). However, using RMS includes some risks (Bradley et al., 2014). Among others, it can contain an important load of gram-negative pathogens (Klebsiella spp., for instance) or food spoilage microorganisms surviving pasteurization such as spore formers and thermoresistant bacteria (Sorter et al., 2014; Leach et al., 2015).

It was demonstrated that dairy farm environment influences milk microbiota (Vacheyrou et al., 2011; Skeie et al., 2019). For example, thermoduric sporeforming bacteria in milk can come from soil, silage, or bedding. A higher number of thermophilic sporeforming bacteria was observed in bulk tank milk of farms using biobedding from composted material such 
as municipal biowaste or wooden chips than farms using sawdust or straw (Driehuis et al., 2014). The principal spore formers in milk are Clostridium (Clostridium sporogenes, Clostridium butyricum, and Clostridium tyrobutyricum), Bacillus (Bacillus cereus and Bacillus sporothermodurans), and Geobacillus (Geobacillus stearothermophilus) (Quigley et al., 2013). Clostridium tyrobutyricum can cause significant defects in cheese such as off-flavors and late blowing (Bassi et al., 2015; Gómez-Torres et al., 2015). As for Bacillus spp., they can produce hydrolytic extracellular enzymes (proteases, lipases, and lecithinases) causing spoilage in pasteurized milk (De Jonghe et al., 2010). The occurrence of the genera Enterococcus and Streptococcus in milk and cheese is also important. Indeed, environmental streptococci, including Streptococcus uberis, Streptococcus dysgalactiae, and enterococci such as Enterococcus spp., can cause mastitis in dairy cows (Cameron et al., 2016). Enterococcus spp. are considered thermoresistant and are associated with the gastrointestinal tract of mammals. Enterococci are also known to be opportunistic nosocomial pathogens worldwide. Their important genome plasticity allows the dissemination of antibiotic resistance genes. There is a major concern for vancomycin-resistant enterococci (VRE), but more specifically for Enterococcus faecium and Enterococcus faecalis species (O'Driscoll and Crank, 2015). Moreover, enterococci are prevalent in dairy products and can have negative effects on flavor development by proteolytic and peptidolytic activities (Giraffa, 2003). Streptococcus thermophilus is a nonpathogenic thermophilic bacterium used in yogurt production that can have a strong acidifying activity (Shahbal et al., 1991). The rates of acidification and proteolytic activity have a critical effect on the texture of cheese (Fox et al., 2017a). In addition, some studies correlated proteolytic and acidifying activity (Giraffa, 2003). As mentioned, bacteria originating from milk can modulate cheesemaking (Fox et al., 2017b). However, to exert considerable influence, those bacteria need to survive to cheese manufacture. In pasteurized cheese production such as Cheddar, different steps can stress bacteria, for example, acidity that comes from the starter, the cooking, and the salting (Gobbetti et al., 2018). The Pearce activity test is an effective laboratory-scale Cheddar cheese simulation to assay bacteria viability (DesfossésFoucault et al., 2014).

High concentrations of thermoduric and thermoresistant bacteria coming from milk of farms using RMS could lead to a reduced shelf life of pasteurized milk and cheese production loss. Therefore, we first investigated, under commercial farms conditions, the effect of RMS compared with straw bedding on the occurrence of spore-forming bacteria and thermoresistant lactic acid bacteria (LAB) in bulk tank milk. Second, the survival, during Cheddar cheese manufacture, of selected thermoresistant strains from RMS-milk sample strains, was evaluated using a laboratory simulation process.

\section{MATERIALS AND METHODS}

\section{Selection of Herds}

The design was a cross-sectional observational study where milk samples from farms using RMS or straw as bedding were compared at a single point in time. To be included in the RMS group, the farms needed to have primarily used these materials as bedding for their lactating cows for at least 6 mo before the study. Almost all farms were composting the RMS before their usage (Table 1). Their herd size was between 55 and 900 cows (mean: 159; median: 111). Farms had to have their main facility within $250 \mathrm{~km}$ of the Faculty of Veterinary Medicine, located at the Université de Montréal (Saint-Hyacinthe, Quebec, Canada). Putative participating herds were identified by contacting (1) equipment dealers; (2) veterinary associations; and (3) via social networks. All identified farm owners using RMS were contacted and asked to participate in the study. Most of these qualified herds are also included in the regular DHI control group; however, the ones using RMS not in the latter were not excluded. Control farms (using straw as bedding) were recruited in the same area using the list provided by Valacta Inc., the Eastern Canada Dairy Herd Improvement Association. These were contacted for participation and selected based only on their exclusive use of straw bedding for the same period. Their herd size was between 43 and 229 cows (mean: 70; median: 65). A total of 84 dairy cow farms were sampled during spring 2018 (26 using RMS and 58 using straw bedding). None of these herds were provided with access to pasture during the sampling period.

Table 1. Information about recycled manure solids production

\begin{tabular}{lc}
\hline Type & No. of farms \\
\hline Separator & 8 \\
Roller press & 18 \\
Screw press & \\
Composting & 1 \\
Biodigester & 13 \\
Box & 2 \\
Tank & 9 \\
Windrow & 1 \\
None & \\
\hline
\end{tabular}




\section{Bulk Tank Milk Sampling}

Before taking the milk samples from farms using RMS (RMS-milk) and farms using straw bedding (straw-milk), the bulk tank was agitated for $5 \mathrm{~min}$. Then, samples were collected by the top of the tank using a straw and a syringe that were both sterilized. Subsequently, the milk was transferred in a sterile conical tube. Whenever the bulk tank milk level was too low to perform the sampling, it was obtained through the outlet valve. A little amount of milk was discarded, and then $50 \mathrm{~mL}$ was collected in a clean sealable bag and then transferred with a syringe into a conical tube; these last 2 items were previously sterilized. Raw milk was kept at $4^{\circ} \mathrm{C}$ until arrival at the laboratory. All samples were analyzed within $48 \mathrm{~h}$.

\section{Enumeration and Isolation of Heat-Resistant Bacteria}

To enumerate thermoduric bacteria (spore-forming bacteria), $15 \mathrm{~mL}$ of raw milk was heated for $10 \mathrm{~min}$ in a water bath at $80^{\circ} \mathrm{C}$ to exclude vegetative cells, then cooled in an ice bath for $10 \mathrm{~min}$. The heated milk was then plated in duplicate for aerobic spore formers on Brain Heart Infusion (BHI) Agar (BD Biosciences, San Jose, CA) supplemented with $1 \mathrm{mg} / \mathrm{L}$ of vitamin $\mathrm{B}_{12}$ (Millipore Sigma, St. Louis, MO) and incubated for 24 to $48 \mathrm{~h}$ at $37^{\circ} \mathrm{C}$ (mesophilic) and $55^{\circ} \mathrm{C}$ (thermophilic) (Driehuis et al., 2014). For mesophilic anaerobic spore-forming bacteria enumeration, heated milk was plated on Reinforced Clostridial Medium (RCM) Agar (HiMedia Laboratories LLC, West Chester, PA) and incubated for 48 to $72 \mathrm{~h}$ at $37^{\circ} \mathrm{C}$ in an anaerobic glove box (Plas-Labs Inc., Lansing, MI) containing an atmosphere of $80 \% \mathrm{~N}_{2}, 10 \% \mathrm{H}_{2}$, and $10 \% \mathrm{CO}_{2}$ (Praxair Canada, Mississauga, ON, Canada; Gómez-Torres et al., 2015). After incubation, the colonies were counted, expressed as colony forming units per milliliter of milk. Second, heat treatment of raw milk was performed at $63^{\circ} \mathrm{C}$ for $10 \mathrm{~min}$ to enumerate thermoresistant $\mathrm{En}$ terococcus and Streptococcus (Carminati et al., 2014). Heated milk and a 10-fold dilution in peptone water (1\% of Bacto Peptone, BD Biosciences) were plated in duplicate on M17 Agar (Oxoid, Nepean, ON, Canada) at 37 and $42^{\circ} \mathrm{C}$ (for S. thermophilus). Colony-forming units were counted after the incubation.

Colonies selected with Harrison's disc (Ricciardi et al., 2015) for each different set of culture conditions were isolated by streaking. Then, pure isolates were grown for $24 \mathrm{~h}$ in the same culture conditions in liquid broth media (BHI, RCM, and M17). They were also kept at $-80^{\circ} \mathrm{C}$ in $20 \%$ (vol/vol) glycerol (EMD Chemicals, Gibbstown, NJ).

\section{Identification of Isolates}

DNA Extraction. Genomic DNA extraction of isolates was performed with Geneaid Presto Mini gDNA Bacteria Kit (FroggaBio, Toronto, ON, Canada). One milliliter of 24-h-old culture was centrifuged at 10,000 $\times g, 10 \mathrm{~min}$ at $4^{\circ} \mathrm{C}$. The cell pellet was used for the extraction. The manufacturer's protocol was modified based on Licitra et al. (2007). Briefly, to improve cell lysis, $20 \mathrm{mg} / \mathrm{mL}$ of lysozyme (Millipore Sigma) and $2.5 \mu \mathrm{L} / \mathrm{mL}$ of mutanolysin $(20 \mathrm{U} / \mu \mathrm{L})$ were added in Gram+ Buffer. Also, each incubation time in a water bath was doubled. The DNA was stored at $-20^{\circ} \mathrm{C}$ until PCR amplification.

$16 S$ rRNA Gene Sequencing. The 16S rRNA genes of all isolates were partially sequenced $(\sim 800$ $\mathrm{bp})$. The amplification was performed with the primers 27F (5'-AGAGTTTGATCCTGGCTCAG-3') and 788R (5'-GGACTACCAGGGTATCTAA-3') (Rasolofo et al., 2010). The reaction for one volume of $50 \mu \mathrm{L}$ contained $200 \mu M$ dNTP mix, $0.2 \mu M$ each primer, $2 \mathrm{mM} \mathrm{MgCl}_{2}$, $1.25 \mathrm{U}$ of GeneDireX Taq DNA polymerase (FroggaBio), and $25 \mathrm{ng}$ of DNA. This volume was supplemented with Invitrogen nuclease-free water (Thermo Fisher Scientific, Waltham, MA). The nuclease-free water was also used as a blank. The amplification in TGradient (Biometra, Montreal Biotech, Montreal, QC, Canada) was performed using the following program: $94^{\circ} \mathrm{C}$ for 5 min, 30 cycles including denaturation at $94^{\circ} \mathrm{C}$ for $30 \mathrm{~s}$, primer annealing at $53^{\circ} \mathrm{C}$ for $1 \mathrm{~min}$, and DNA extension at $72^{\circ} \mathrm{C}$ for $2 \mathrm{~min}$, and a final step also at $72^{\circ} \mathrm{C}$ for 5 min. Next, DNA sequence analysis was carried out on both strands of the purified PCR products with the BigDye Terminator v3.1 Cycle Sequencing Kit and 3100 Genetic Analyzer System (Thermo Fisher Scientific). Sequences were aligned using Geneious Pro R6 software (Biomatters, San Francisco, CA). Identification was obtained with the Nucleotide Basic Local Alignment Search Tool (https://blast.ncbi.nlm.nih.gov/). Further PCR amplifications were carried out for better identification of isolates belongs to Enterococcus species and S. thermophilus group.

Identification of Enterococci by Multiplex $P C R$. Enterococcus multiplex PCR was performed as described by Layton et al. (2010) to identify Enterococcus avium, Enterococcus casseliflavus, Enterococcus durans, Enterococcus gallinarum, Enterococcus faecium, Enterococcus faecalis, Enterococcus hirae, Enterococcus saccharolyticus, and Enterococcus italicus. Positive controls (Enterococcus hirae ATCC 10541, Enterococcus faecium 11G22K, Enterococcus faecalis ATCC 27275, and Enterococcus durans DSM-20633) and negative controls (Lactococcus lactis ssp. cremoris SK11 and E. italicus DSM-15952) were used. No primer was designed for $E$. 
italicus. However, if isolates, identified as E. durans/ italicus by $16 \mathrm{~S}$ rRNA gene sequencing, were negative to the $E$. durans assay, they were assumed to belong to $E$. italicus. The PCR conditions and primers are shown in Supplemental Tables S1, S2, and S3 (https://doi.org/ 10.3168/jds.2019-16812). Nuclease-free water was used as blank. After the reaction, $5 \mu \mathrm{L}$ of PCR products was analyzed with GD 100 bp DNA Ladder H3 (FroggaBio) by electrophoresis on 1.5\% agarose gel (Thermo Fisher Scientific) containing Red Safe (FroggaBio). Migration was performed using a sodium boric acid buffer (Brody and Kern, 2004) $45 \mathrm{~min}$ at $135 \mathrm{mV}$.

Identification of Streptococcus thermophilus. Isolates belonging to the taxonomic group of $S$. thermophilus/salivarius were distinguished by PCR amplification of the lac $Z$ gene. The technique was performed as described by Lick et al. (1996). The PCR conditions and primers are shown in Supplemental Tables S4 and S5 (https://doi.org/10.3168/jds.2019-16812). The PCR products (968 bp) were analyzed as previously mentioned. Streptococcus thermophilus ATCC 19258 was used as a positive control and nuclease-free water as blank.

\section{Proteolytic Enzyme Test}

The proteolytic activity of enterococci and streptococci isolates was assayed as described by Franciosi et al. (2009). Briefly, $2 \mu \mathrm{L}$ of $16 \mathrm{~h}$ culture in M17 broth, after 2 subcultures, were dropped on Skim Milk Agar [10\% skim milk powder (local supplier, QC, Canada) and 2\% agar (Hardy Diagnostics, Santa Maria, CA)]. The plates were incubated for $4 \mathrm{~d}$ at $37^{\circ} \mathrm{C}$. Proteolytic activity (clear halo around the colony) were measured (Supplemental Figure S1, https://doi.org/10.3168/jds .2019-16812). Halo diameter ranged from 16 to $23 \mathrm{~mm}$ corresponding to a strong proteolytic activity and halo diameter ranged from 9 to $16 \mathrm{~mm}$ corresponding to a low proteolytic activity. No halo corresponded to a negative proteolytic activity.

\section{Detection of VRE}

Multiplex PCR assay for detection of 7 types of VRE determinants $(\operatorname{van} A, \operatorname{van} B, \operatorname{van} C 1, \operatorname{van} C 2 / 3, \operatorname{vanD} / D 4$, van $M$, and $\operatorname{van} N$ ) were performed as described by Nomura et al. (2018). The PCR conditions and primers are shown in Supplemental Tables S6, S7, and S8 (https:/ /doi.org/10.3168/jds.2019-16812). The PCR products were analyzed as previously mentioned. VanB-type $E$. faecalis ATCC 51299 was used as a positive control and E. durans DSM-20633 as negative control. For VRE determinants detected, the MIC was determined by mi- crodilution method in triplicate following CLSI guidelines (Clinical Laboratory Standards Institute, 2012). The MIC is the highest dilution of antibiotic showing complete inhibition of the tested strain [approximate optical density equals optical density of the blank (M17 broth) measured at $565 \mathrm{~nm}$ ].

\section{Pearce Activity Test}

The Pearce activity test (Cheddar manufacture model) was performed as described by DesfossésFoucault et al. (2014) to evaluate the effect of selected thermoresistant LAB associated with RMS milk. Four strains were selected $[2$ proteolytic E. faecalis (M155 and M236), 1 non-proteolytic E. faecalis (M390), and $1 S$. thermophilus (M388)]. These isolates of E. faecalis originated from milk of different farms using RMS. Microbial population and acidification curve during the production of cheese model were monitored. From the frozen culture, the reference Cheddar starter $L$. lactis ssp. cremoris SK11 and the selected thermoresistant LAB were subcultured twice and were grown in microfiltered containing $3.25 \%$ fat (local supplier, ON, Canada). Briefly, during the Pearce activity test, microfiltered milk was inoculated with the starter at $10^{7} \mathrm{cfu} / \mathrm{mL}$ and with the thermoresistant LAB separately at $10^{6} \mathrm{cfu} / \mathrm{mL}$. Not inoculated milk was used as the negative control. Steps and sampling times are shown in Figure 1. At each of the latter, the $\mathrm{pH}$ was measured, and viable counts were performed. One milliliter of milk, or $1 \mathrm{~g}$ of curds, was taken and mixed for 5 min at $260 \mathrm{rpm}$ in Stomacher 400 Circulator (Seward Laboratory Systems Inc., West Sussex, UK) with $9 \mathrm{~mL}$ of sodium citrate $2 \%$ (wt/vol). Then, the appropriate dilution was plated on M17 Agar for the starter, ST

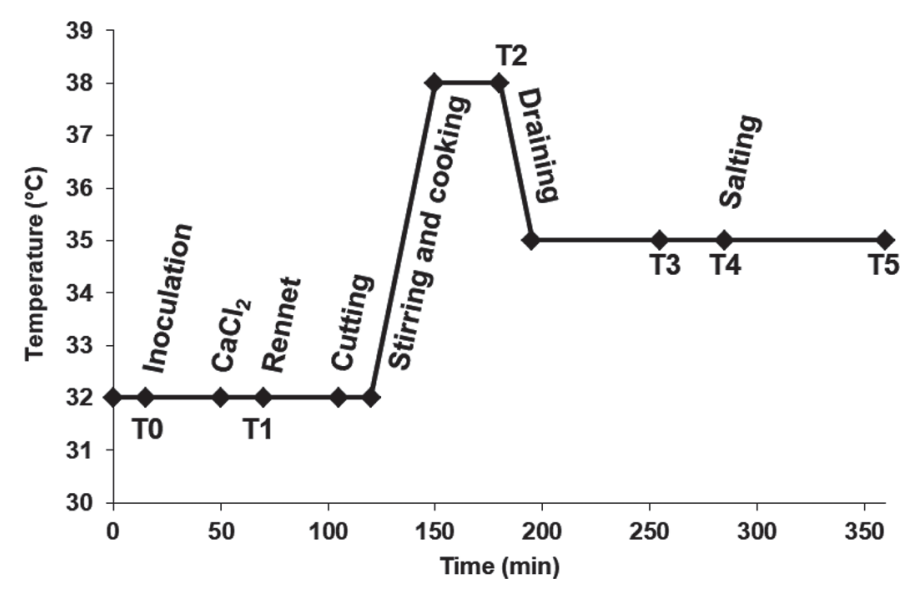

Figure 1. Temperature profile, steps, and sampling points (T0-T5) of the Pearce activity test. 
Agar for S. thermophilus (Ashraf and Shah, 2011), and MacConkey Agar without crystal violet for E. faecalis (Savard et al., 2011). The experiment was performed in triplicate.

\section{Statistical Analysis}

Comparisons were made between RMS-milk and straw-milk. Analyses were conducted both including and excluding the 2 farms where RMS was not composted. This did not influence summary measures of counts or STAMP analysis or the significance of differences between RMS-milk and straw-milk. Therefore, the results including all RMS samples are presented. Differences in viable counts of thermoduric and thermoresistant bacteria between bedding types were determined with JMP 13 Software (SAS Institute Inc., Cary, NC), using nonparametric Wilcoxon test as the data did not exhibit a normal distribution. The relative abundance of taxonomic groups were compared with STAMP version 2.1.3 (Parks et al., 2014) following data transformation in the R environment (R Core Team, 2013) using Phyloseq (McMurdie and Holmes 2013) and Microbiome (Lahti et al., 2017) packages. Significance was assessed with a 2-tailed Welch's $t$-test, and the Storey's false discovery rate correction was applied on $P$-values. Chisquared test was conducted to determine if there was difference in presence or absence of proteolytic streptococci or enterococci between RMS-milk and straw-milk. Pearce activity test viable counts and $\mathrm{pH}$ values were compared by an ANOVA performed with JMP 13. The means were multi-compared using the Tukey's honestly significant difference test.

\section{RESULTS}

\section{Effect of Bedding Type on Thermoduric and Thermoresistant Bacteria Viable Counts in Milk}

First, no significant difference was observed in viable counts of aerobic mesophilic spore-forming bacteria between the 2 types of milk $(\mathrm{Z}$ value $=-0.88 ; P=$ 0.38 ; Figure 2). Similar values for aerobic thermophilic spore-forming species were determined in milk and no significant difference was observed $(\mathrm{Z}$ value $=-1.12$; $P=0.26)$. Bedding types had an effect on anaerobic mesophilic viable counts from spores $(\mathrm{Z}$ value $=-2.25$; $P=0.02$; Figure 2 ). The mean values obtained for milk samples from farms using straw bedding were higher than those using RMS; they were, respectively, 0.44 and $0.17 \log \mathrm{cfu} / \mathrm{mL}$ of fluid. As for thermoresistant bacteria, viable counts were not affected by the bed- ding type during an incubation at $37^{\circ} \mathrm{C}$, or at $42^{\circ} \mathrm{C}$ $\left(37^{\circ} \mathrm{C}: \mathrm{Z}\right.$ value $=0.97 ; P=0.33 ; 42^{\circ} \mathrm{C}: \mathrm{Z}$ value $=0.34$ $P=0.74$; Figure 2).

A total of 90 mesophilic and 69 thermophilic aerobic spore-forming bacteria were isolated from milk samples. Ten different taxonomic groups of Bacillaceae were identified, belonging mostly to the genus Bacillus (Figure 3A). The other genera were Lysinibacillus, Gracilibacillus, and Geobacillus. Bacillus licheniformis was the dominant species, accounting for $68 \%$ of mesophilic and $93 \%$ of thermophilic bacteria. The other ones identified belonging to the genus Bacillus were B. circulans, B. clausii, B. megaterium, B. pumilus/altitudinis/ safensis/zhangzhouensis, B. subtilis/tequilensis, and B. thermoamylovorans. Statistical analyses performed with STAMP indicated that Bacillus spp. were significantly more abundant in straw-milk samples (Figure 4A), but this difference was explained by anaerobic spore formers. As previously mentioned, milk samples from farms using RMS had a smaller number of anaerobic spore-forming bacteria than those using straw bedding. Five isolates were found in RMS-milk samples against 43 in straw-milk samples. Bacillus licheniformis was the most abundant taxonomic group in anaerobic spore formers. Furthermore, it was significantly more abundant in straw-milk samples (Figure 4B). On the other hand, RMS-milk samples contained more Lysinibacillus sphaericus/halotolerans/massiliensis.

In total, 432 isolates of thermoresistant bacteria were collected on M17 agar, 141 of these from RMS-milk samples (77 isolates at $37^{\circ} \mathrm{C}$ and 64 at $42^{\circ} \mathrm{C}$ ) and the 291 remaining from milk samples of straw bedding (152 isolates at $37^{\circ} \mathrm{C}$ and 139 at $42^{\circ} \mathrm{C}$ ). The LAB identified belonged to 4 genera [i.e., Enterococcus, Lactobacillus, Leuconostoc, and Streptococcus (Figure 3B)]. The genus Kocuria is not part of LAB but of the Micrococcaceae family; members were also present. As expected, more isolates of $S$. thermophilus were recovered when M17 Agar preparations were incubated at $42^{\circ} \mathrm{C}$. Unlike thermoduric bacteria, the profiles of thermoresistant ones from RMS- and straw-milk samples were different. According to STAMP analysis, among all the isolates recovered at both 37 and $42^{\circ} \mathrm{C}$, only the relative abundance of the genus Streptococcus varied significantly, with nearly 7 times higher values in RMS-milk samples (20\%) compared with straw-milk samples (3\%; Figures $3 \mathrm{~B}$ and $4 \mathrm{~A})$. At the species level, no significant difference in isolates was observed when comparing the 2 groups of farms. However, when comparing isolates from the 2 groups of farms at each incubation temperature separately, the STAMP analysis was showing that the relative abundance varied significantly only at $37^{\circ} \mathrm{C}$. Kocuria kristinae and Kocuria rhizophila/salsicia 
were twice as abundant as in straw-milk samples than in RMS-milk samples (Figure 4C). The abundance of Enterococcus spp. was comparable in both types of bedding (39\%; Figure 3B). Nevertheless, in enterococci, $E$. faecalis was significantly more present in RMS-milk samples than in straw-milk samples. Unlike E. faecalis, E. faecium significantly was more abundant in the latter (16\% in RMS-milk samples versus $20 \%$ in strawmilk samples; Figures 3B and 4C).

\section{Proteolytic Activity of Streptococci and Enterococci}

Out of 208 enterococci and streptococci tested, only 21 isolates identified as E. faecalis had positive proteolytic activities (Table 2). The prevalence of farms contained proteolytic E. faecalis in milk samples was
$7 \%$ for farms using straw bedding (5/58) compared with $15 \%$ for farm using RMS $(4 / 26)$. However, this difference was not significant $(P=0.37)$.

\section{Vancomycin Resistance of Enterococci}

Out of 171 thermoresistant enterococcal isolates, 1 strain, E. gallinarium/casseliflavus M530, had vancomycin-resistance associated genes. This strain was isolated from RMS-milk. The M530 strain had 2 genotypes, $\operatorname{vanN}(941 \mathrm{bp}$ ) and $\operatorname{van} C 1$ (836 bp). The VanB gene of $E$. faecalis ATCC 51299 was also detected (640 bp). In the present study, the MIC calculated of the vancomycin-resistant E. faecalis ATCC 51299 and vancomycin-sensitive $E$. durans DSM-20633 was, respectively, 62.5 and $1.95 \mu \mathrm{g} / \mathrm{mL}$. Vancomycin resistance of

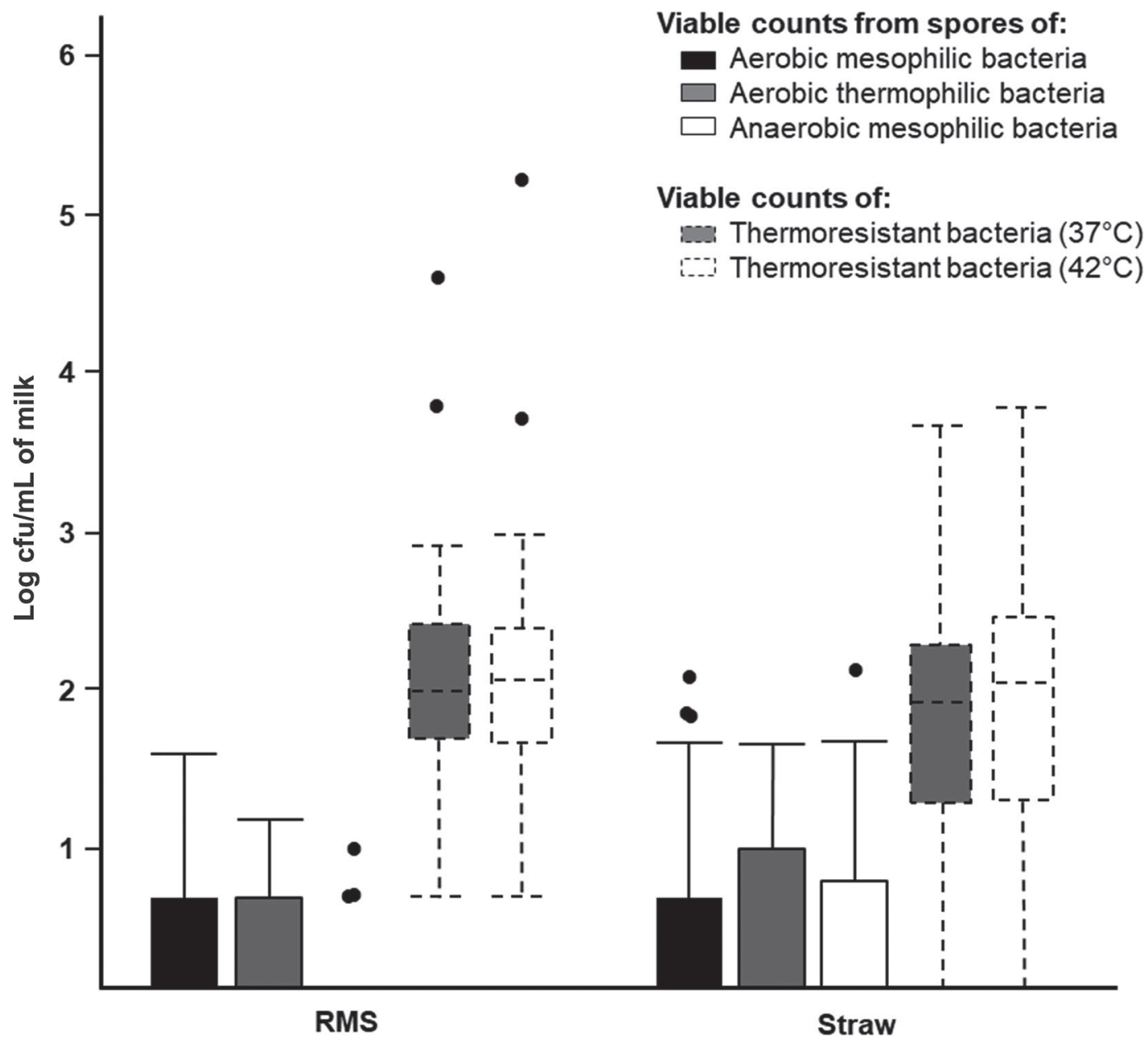

Figure 2. Box plot created from viable counts of thermoduric (spore of aerobic mesophilic, aerobic thermophilic, and anaerobic mesophilic bacteria) and thermoresistant bacteria in bulk tank milk from farms using recycled manure solids (RMS) or straw bedding. Thermoresistant bacteria were incubated at 2 temperatures: 37 and $42^{\circ} \mathrm{C}$. The lines represent the median and the ends of the box represent the 1 st and $3 \mathrm{rd}$ quartiles. The whiskers represent 1st quartile $-1.5 \times$ (interquartile range) and 3rd quartile $+1.5 \times$ (interquartile range), and the dots represent the outliers. 
E. gallinarium/casseliflavus M530 was confirmed with a MIC of $15.6 \mu \mathrm{g} / \mathrm{mL}$.

\section{Effect of Thermoresistant Bacteria from RMS in Cheddar Manufacture}

Two proteolytic E. faecalis (M155 and M236), 1 nonproteolytic E. faecalis (M390), and 1 S. thermophilus (M388) isolates from RMS-milk samples were selected. The 4 thermoresistant strains grew well during the Pearce activity test (Figure 5A). The viable counts of E. faecalis and $S$. thermophilus strains were significantly different at the salting step at 285 min (sampling point T4). At this sampling point, S. thermophilus M388 was assessed at a higher concentration than E. faecalis M236 and M390 $(F$ value $=7.2031 ; P=0.0116)$. After the salting step, $S$. thermophilus M388 was less cultivable and E. faecalis M155 stayed stable. However, for the other strains M236 and M390, viable counts increased between sampling points $\mathrm{T} 4$ and $\mathrm{T} 5$. Therefore, at the 360-min time point, the 4 thermoresistant strains had the same concentration. Even if these grew during the Cheddar manufacture, they did not inhibit nor improve significantly the growth of the starter L. lactis ssp. cremoris SK11 (Figure 5B). As for the starter viable counts, the presence of the thermoresistant LAB selected did not affect the acidification curve despite their growth $(P>0.05$; Figure 5C). Milk was acidified by the starter L. lactis ssp. cremoris SK11, a process during which the $\mathrm{pH}$ shifted from 6.56 to 5.49 after $6 \mathrm{~h}$ of manufacture.

\section{DISCUSSION}

The thermoduric and thermoresistant bacteria concentrations were no higher in raw milk originating from farms using RMS compared with samples from those using straw bedding (Figure 2). This result corroborates that of Bradley et al. (2018) who showed that the bedding type (not composted RMS, sand, and sawdust) did not affect the total bacterial count in bulk tank milk, even though counts in the bedding material itself were higher when RMS was used, compared with sand or sawdust. Rowbotham and Ruegg (2015) found similar results. In their study comparing the following bedding materials: inorganic, organic nonmanure, and manure-based, no association was observed between total bacterial count in bulk tank milk and bedding type. The composting of bedding has been associated with an increase of thermophilic aerobic spore-forming bacteria in milk (Driehuis et al., 2014). However, in our study almost all farms used composting RMS but no significant differences were observed compared with straw bedding. Moreover, the inclusion or exclusion of the 2 farms that did not compost RMS did not affect the findings. This would imply that most of the bacterial population in milk originated from the mammary gland, rather than from contamination during harvest-
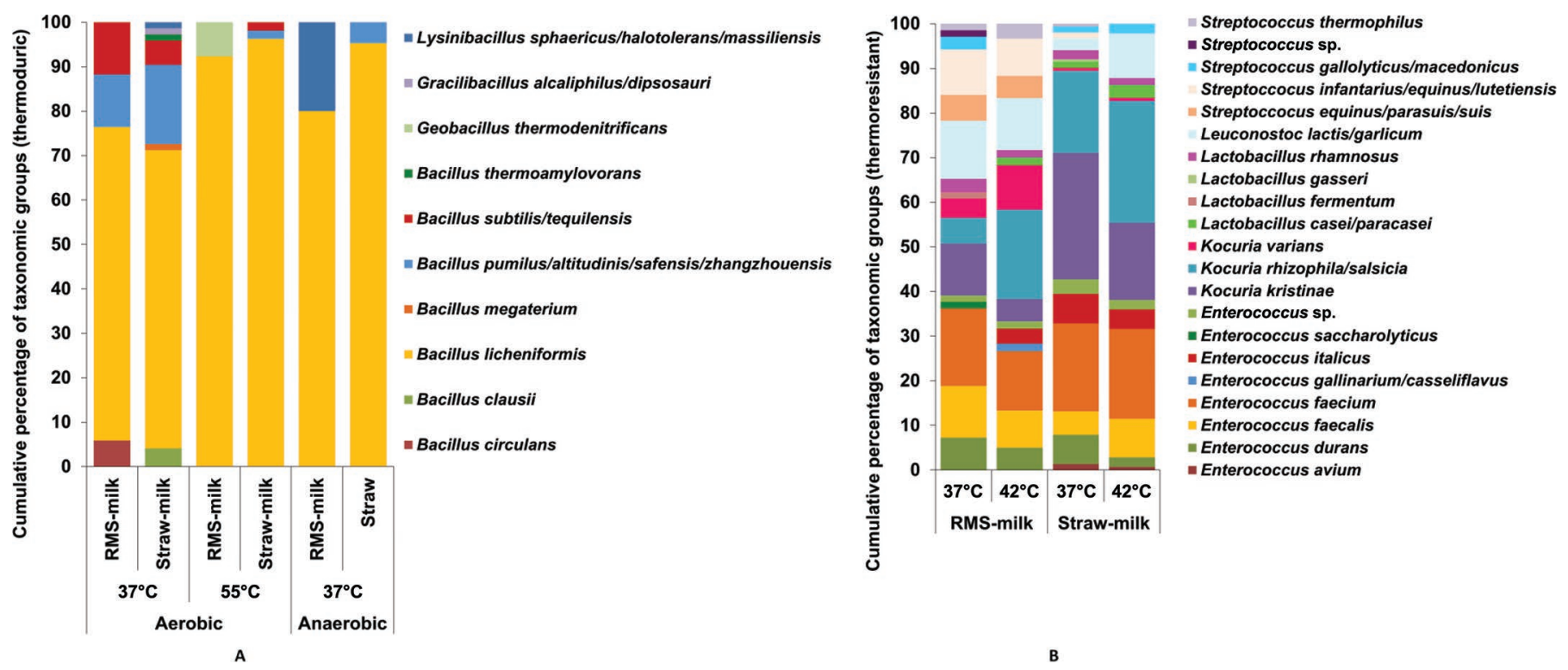

Figure 3. Cumulative percentage distinguishing taxonomic groups from farm using recycled manure solids (RMS) and straw as bedding of (A) spore-forming bacteria isolated from milk heated at $80^{\circ} \mathrm{C}$, for $10 \mathrm{~min}$, and (B) bacteria isolated on $\mathrm{M} 17$ agar at 37 and $42^{\circ} \mathrm{C}$ from milk heated at $63^{\circ} \mathrm{C}$, for $10 \mathrm{~min}$. 
A

$95 \%$ confidence intervals

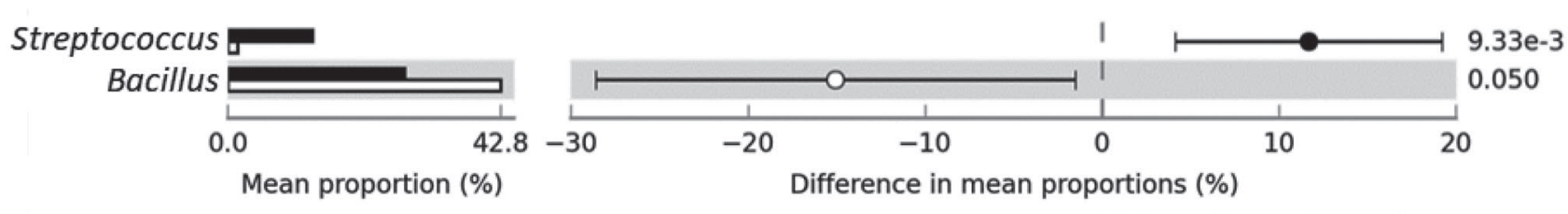

B

Lysinibacillus sphaericus/halotolerans/massiliensis Bacillus megaterium | Bacillus clausii | Bacillus licheniformis Bacillus pumilus/altitudinis/safensis/zhangzhouensis

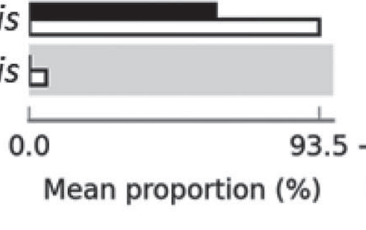

$95 \%$ confidence intervals

C
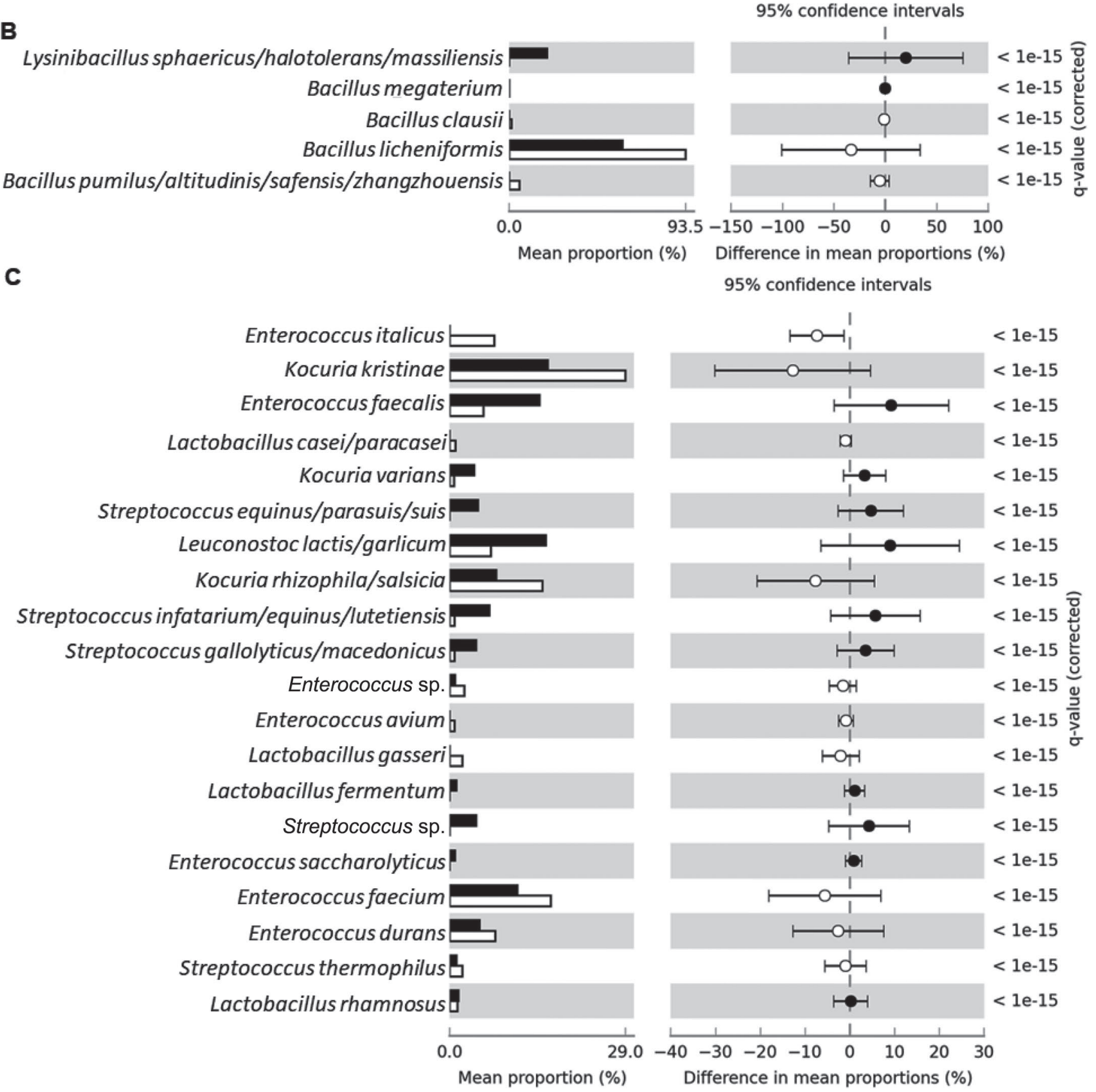

Figure 4. Statistical analysis of thermoduric and thermoresistant taxonomic groups isolated from milk samples from farms using recycled manure solids (in black) and straw (in white) as bedding using STAMP version 2.1.3 software (Parks et al., 2014). Storey's false discovery rate correction was applied when means were multi-compared. (A) Genus comparison for all growth conditions, (B) species comparison for anaerobic growth, and (C) species comparison for M17 at $37^{\circ} \mathrm{C}$. The error bars represent calculated CI. 
A
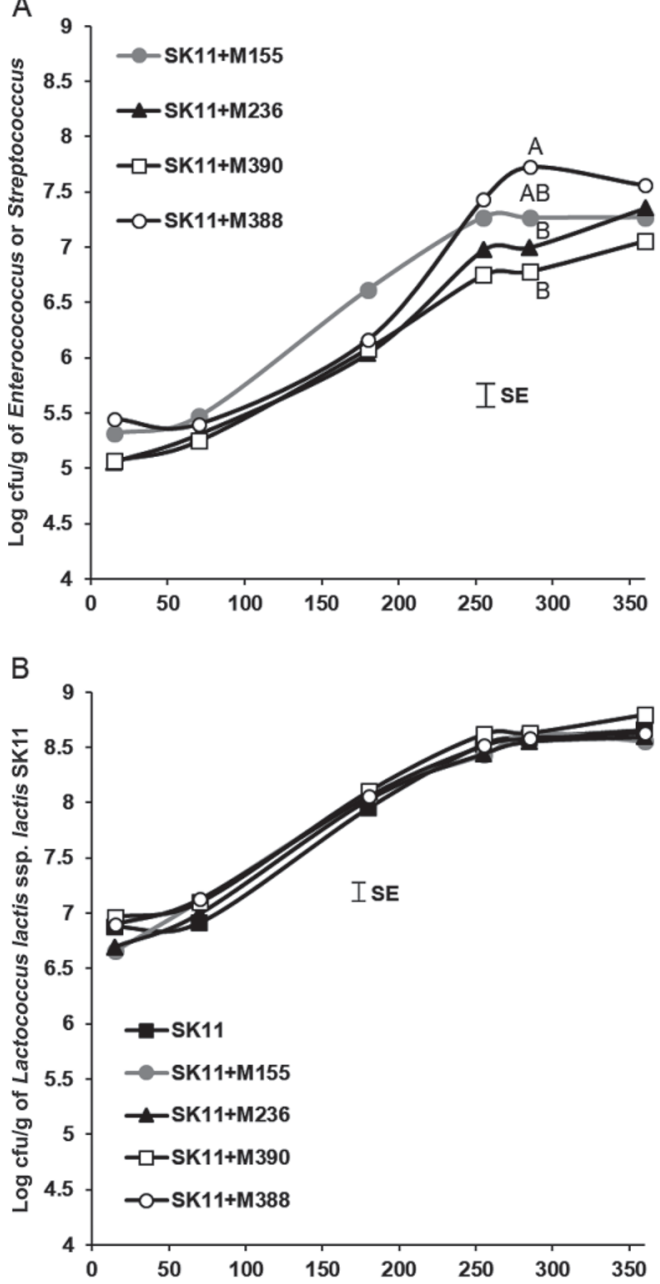

C

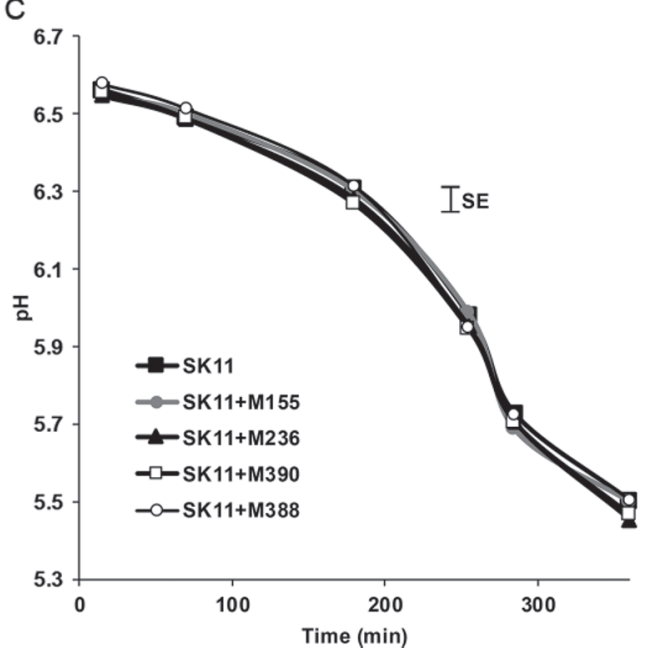

Figure 5. Pearce activity test viable counts of (A) thermoresistant Enterococcus faecalis M155, M236, and M390 or Streptococcus thermophilus M388 and (B) starter Lactococcus lactis subsp. cremoris SK11 and (C) Pearce activity test acidification curves with the starter L. lactis subsp. cremoris SK11 and inoculation of SK11 mixed cultures. The error bars represent the SE. Means with distinct capital letters were significantly different $(P<0.05)$.
Table 2. Thermoresistant Enterococcus faecalis with positive proteolytic activity isolated from bulk tank milk collected from farms using straw or recycled manure solids (RMS) as bedding

\begin{tabular}{lll}
\hline Isolate code & Farm code & Proteolytic activity $^{1}$ \\
\hline Straw & & \\
M097 & 1243 & ++ \\
M285 & 1261 & + \\
M284 & & ++ \\
M282 & & ++ \\
M283 & & ++ \\
M287 & 1272 & + \\
M436 & & + \\
M437 & & ++ \\
M450 & & ++ \\
M447 & 1273 & ++ \\
M441 & 1288 & ++ \\
M680 & & + \\
RMS & 1104 & + \\
M155 & 1109 & + \\
M242 & & + \\
M239 & & ++ \\
M240 & & ++ \\
M237 & & + \\
M234 & 1123 & ++ \\
M236 & 1127 & + \\
M500 & & + \\
M689 & & \\
\hline
\end{tabular}

${ }^{1}++=$ halo diameter ranged from 16 to $23 \mathrm{~mm} ;+=$ halo diameter ranged from 9 to $16 \mathrm{~mm}$.

ing. Bradley et al. (2018) demonstrated a difference in thermophilic spore counts between 3 bedding materials (RMS, sand, and sawdust) but no influence of bedding type on the thermophilic spore counts in the milk produced. The thermophilic viable count from spores was higher $(\sim 2 \log \mathrm{cfu} / \mathrm{mL})$ than in the present study. This could be explained by the difference in climate between the United Kingdom and Canada. Also, in the present study, samples were collected only in spring in comparison to December to March. Our results are more similar to those of Buehner et al. (2014). The spores count in raw milk collected in winter in the Midwest of the United States were, respectively, 0.69 and $0.39 \log$ $\mathrm{cfu} / \mathrm{mL}$ for mesophilic spores and thermoduric spores. The authors showed an increase of spores count during summer. Other factors, for example use of silage could influence the concentration of spore-forming bacteria in milk (Driehuis, 2013; Buehner et al., 2014), but no information about feeding type was collected in the present study.

The identification of isolates in the current study has shown that aerobic spore-forming bacteria are similar in milk samples regardless of the bedding type (Figure 3A). Bacillus licheniformis appeared to be adapted to different culture conditions, as it was the most abundant species among the aerobic (thermophilic and mesophilic) and anaerobic spore formers. Our results are in agreement with the study of Coorevits et al. (2008) 
who demonstrated the dominance of B. licheniformis in milk from organic and conventional dairy farms. In the present study, anaerobic B. licheniformis was more abundant in milk from farm using straw bedding. This species has already been reported to grow in anaerobic conditions (Clements et al., 2002). Bacillus licheniformis anaerobic respiration using nitric oxide reductase is possible (Rey et al., 2004). This type of enzyme is associated with denitrification (Hendriks et al., 2000) and could explain the presence of anaerobic B. licheniformis in soil, and transfer to straw bedding. Another difference in anaerobic spore formers was the presence of Lysinibacillus sphaericus/halotolerans/massiliensis only in RMS-milk samples. Members of the genus $L y$ sinibacillus have previously been isolated in bulk tank milk but was not linked to particular management practices (Miller et al., 2015). Moreover, Lysinibacillus spp. are common in dairy cow fecal microbiota (Mao et al., 2012) and could be associated with RMS. However, this is to be taken lightly considering the limited number of isolates, especially since they did not show strong proteolytic activities in milk, neither cytotoxicity nor toxigenic activities (De Jonghe et al., 2010). Anaerobic spore-forming $C$. butyricum was a major concern regarding the use of RMS for cheese defects (Driehuis et al., 2013). Fortunately, we did not detect cultivable $C$. tyrobutyricum in RMS- or straw-milk samples. Bacillus cereus, an important food pathogen, was not found in bulk tank milk. Based on our results, using RMS does not seem to affect the occurrence of bacterial spores in milk.

The identification of bacteria isolated on M17 Agar demonstrated that this medium was not specific to LAB because numerous strains of Kocuria spp. were collected (Figure 3B). Some studies indicated that their growth can be supported on M17 medium (Renye et al., 2011; Yunita and Dodd, 2018). Therefore, we obtained thermoresistant bacteria profiles rather than thermoresistant LAB profiles. These were affected by milk origin. Kocuria spp. were more abundant in straw-milk samples. This genus is common in the dairy environment (Quigley et al., 2013) and isolates have already been reported in pasteurized milk samples (Coorevits et al., 2008). Kocuria spp. were found in farm air and hay (Lis et al., 2008; Vacheyrou et al., 2011). Furthermore, $K$. kristinae has been isolated from biofilms covering wooden vats collected in a farm (Licitra et al., 2007). However, it is not clear if the higher abundance of this genus, more specifically $K$. rhizophila/salsicia and $K$. kristinae, is related directly to straw bedding.

The use of RMS was associated with a higher abundance of thermoresistant Streptococcus spp. and E. faecalis in milk (Figures 3B and 4). Zdanowicz et al. (2004) revealed a positive correlation between bacterial populations, including Streptococcus spp., in the sand bedding and on the teat skin. Indeed, some studies indicated a high quantity of Streptococcus spp. in RMS [e.g., 9 (Sorter et al., 2014) and $6 \log \mathrm{cfu} / \mathrm{g}$ of DM (Fournel et al., 2019b)]. Fournel et al. (2019b) demonstrated that solid-liquid separation methods and composting time did not affect their number in RMS. Also, Streptococcus spp. can grow in the RMS obtained by composting, from 4.8 to $8.7 \mathrm{log} \mathrm{cfu} / \mathrm{g}$ of DM (Cole and Hogan, 2016). Therefore, higher levels in RMS-milk samples could be linked to their presence in the bedding. This could be an issue since environmental streptococci other than $S$. uberis and S. dysgalactiae, such as $S$. gallolyticus and $S$. lutetiensis, can cause mastitis in dairy cows (Cameron et al., 2016). This infection increases the number of somatic cells in raw milk. A high count of those reduces the product yield of Cheddar cheese (Auldist et al., 1996). However, it is not clear in the literature that RMS increase the prevalence of clinical mastitis (Leach et al., 2015). Future investigations will be needed on this point. Despite the fact that in our study $S$. thermophilus M388 did not affect the Cheddar manufacture (Figure 5), the presence of this species in RMS-milk samples is also worrying for cheesemakers. Indeed, some strains can form biofilms on stainless steel. These can cause many problems in cheese manufacturing plants such as undesirable contamination of dairy products and uncontrolled milk acidification during food production (Bassi et al., 2017).

The equivalent abundance of enterococci in the 2 types of milk is not surprising as they are present not only in cow feces, but also in soil and plants (Gelsomino et al., 2002). In comparison to environmental streptococci having a continued susceptibility to $\beta$-lactam antimicrobials (Cameron et al., 2016), the higher abundance of E. faecalis in RMS-milk sample could be of concern, given that this species has been identified as resistant to the glycopeptide antimicrobial vancomycin (O'Driscoll and Crank, 2015). Moreover, this species has a high potential for pathogenicity. However, we have not detected any vancomycin-resistant determinants belonging to this species. The low VRE strain, E. gallinarium/casseliflavus M530, collected in a milk sample from a farm using RMS, had the vanC and $\operatorname{van} N$ genotype. The chromosomic $\operatorname{van} C$ gene is intrinsic to E. gallinarum and E. casseliflavus species and corresponds to a low resistance to vancomycin (MIC between 2 and $32 \mu \mathrm{g} / \mathrm{mL}$ ). Like $\operatorname{vanC}$, the presence of $\operatorname{van} N$ gene produces a low vancomycin-resistant phenotype (MIC of $15 \mu \mathrm{g} / \mathrm{mL}$ ). The presence of this gene can be problematic as it is in plasmid (O'Driscoll and Crank, 2015). VanN-type E. faecium strains were reported in clinical settings in Canada and in chicken meat in Japan (Nomura et al., 2018). However, we can- 
not link the E. gallinarium/casseliflavus M530 strain directly to the use of RMS. The multiplex PCR test used in this study could be used to detect VRE in RMS directly in future studies.

Enterococcus faecalis isolated from RMS-milk did not affect the Cheddar manufacture as the strains tested did not modify the acidification curve. Nevertheless, the number of those bacteria increased during the $6 \mathrm{~h}$ of cheese production. This suggests that their presence would be elevated at the beginning of the ripening, and as such, given the proteolytic activity of species like $E$. faecalis, noxious effects could occur during this step. The addition of salt in the curd helps to control microbial metabolism, such as proteolysis (Fox et al., 2017b). However, 2 E. faecalis strains (M236 and M390) and E. faecium M361 isolated from RMS-milk samples have shown a $\mathrm{NaCl}$ tolerance. Uncontrolled proteolysis of casein can have a major effect on the Cheddar texture (Lawrence et al., 2004). Also, the breakdown of proteins followed by the catabolism of AA can produce off-flavor volatile compounds (Singh et al., 2003; Lawrence et al., 2004). As bulk tank samples from farms using RMS contained more thermoresistant Streptococcus spp. and E. faecalis, the milk could be prioritized for fresh cheese (no ripening step). Otherwise, it could be microfiltered before cheesemaking. Moreover, the RMS production is not standardized in Canada. Further studies on RMS production could help to limit spoilage and pathogen bacteria such as enterococci and streptococci (Fournel et al., 2019a,b).

\section{CONCLUSIONS}

Our study investigated under farm conditions the effect of RMS bedding used in dairy farms on thermoduric and thermoresistant milk microbiota in comparison to conventional straw bedding. Aerobic spore formers and thermoresistant bacteria concentrations in milk were not higher in milk samples from farms using RMS. However, RMS bedding introduces an increased risk of having thermoresistant streptococci and enterococci in milk. Potentially, E. faecalis strains with proteolytic activity and $\mathrm{NaCl}$ tolerance could be noxious for Cheddar cheese ripening. Therefore, it remains important to assess the effect of new farm management practices on milk quality. This knowledge could help cheesemakers to select milk (e.g., use of milk from RMS farms for fresh cheese with no ripening step). To assure the milk producers and the cheesemakers that the RMS bedding is safe, future work using metagenomics to also target viable but nonculturable bacteria will have to be done. Moreover, because the use of RMS is relatively new, the different production methods will have to be compared in combination with milk quality.

\section{ACKNOWLEDGMENTS}

The authors thank the Natural Sciences and Engineering Research Council of Canada (NSERC), Novalait, Agriculture and Agri-Food Canada, and the Fonds de recherche du Québec-Nature et technologies (FRQNT) for their financial contribution. They also give special thanks to the $\mathrm{Op}^{+}$Lait research group which allowed the creation and realization of this project. The authors also thank all members of S. Dufour's and D. Roy's teams for their technical assistance and scientific advice, particularly Alexandre Jules Kennang Ouamba (Faculté des sciences de l'agriculture et alimentation, Université Laval, Québec, Canada) in regard to the statistical analysis and Caroline Forest (Faculté de médecine vétérinaire, Université de Montréal, St-Hyacinthe, Canada) for technical assistance during the collection of samples. The authors sincerely thank Dominique Fournier (www.serviceslinguistiquesdf.com) for editing and improving the text of the manuscript.

\section{REFERENCES}

Ashraf, R., and N. P. Shah. 2011. Selective and differential enumerations of Lactobacillus delbrueckii ssp. bulgaricus, Streptococcus thermophilus, Lactobacillus acidophilus, Lactobacillus casei and Bifidobacterium spp. in yoghurt — A review. Int. J. Food Microbiol. 149:194-208. https://doi.org/10.1016/j.ijfoodmicro.2011.07.008.

Auldist, M. J., S. Coats, B. J. Sutherland, J. J. Mayes, G. H. McDowell, and G. L. Rogers. 1996. Effects of somatic cell count and stage of lactation on raw milk composition and the yield and quality of Cheddar cheese. J. Dairy Res. 63:269-280. https://doi.org/10 .1017/S0022029900031769.

Bassi, D., F. Cappa, S. Gazzola, L. Orrù, and P. S. Cocconcelli. 2017. Biofilm formation on stainless steel by Streptococcus thermophilus UC8547 in milk environments is mediated by the proteinase PrtS. Appl. Environ. Microbiol. 83:e02840-16. https://doi.org/10.1128/ AEM.02840-16.

Bassi, D., E. Puglisi, and P. S. Cocconcelli. 2015. Understanding the bacterial communities of hard cheese with blowing defect. Food Microbiol. 52:106-118. https://doi.org/10.1016/j.fm.2015.07.004.

Bradley, A. J., K. A. Leach, S. C. Archer, J. E. Breen, M. J. Green, I. C. Ohnstad, and S. Tuer. 2014. Scoping study on the potential risks (and benefits) of using recycled manure solids as bedding for dairy cattle. Report prepared for DairyCo. Accessed Apr. 15, 2019. https://dairy.ahdb.org.uk/resources-library/technical -information/buildings/rms-bedding.

Bradley, A. J., K. A. Leach, M. J. Green, J. Gibbons, I. C. Ohnstad, D. H. Black, B. Payne, V. E. Prout, and J. E. Breen. 2018. The impact of dairy cows' bedding material and its microbial content on the quality and safety of milk-A cross sectional study of UK farms. Int. J. Food Microbiol. 269:36-45. https://doi.org/10.1016/ j.ijfoodmicro.2017.12.022.

Brody, J. R., and S. E. Kern. 2004. Sodium boric acid: A Tris-free, cooler conductive medium for DNA electrophoresis. Biotechniques 36:214-216. https://doi.org/10.2144/04362BM02.

Buehner, K. P., S. Anand, G. D. Diira, and A. Garcia. 2014. Prevalence of thermoduric bacteria and spores on 10 Midwest dairy farms. J. Dairy Sci. 97:6777-6784. https://doi.org/10.3168/jds .2014-8342.

Cameron, M., M. Saab, L. Heider, J. T. McClure, J. C. RodriguezLecompte, and J. Sanchez. 2016. Antimicrobial susceptibility patterns of environmental streptococci recovered from bovine milk 
samples in the maritime provinces of Canada. Front. Vet. Sci. 3:79. https://doi.org/10.3389/fvets.2016.00079.

Carminati, D., F. Tidona, M. E. Fornasari, L. Rossetti, A. Meucci, and G. Giraffa. 2014. Biotyping of cultivable lactic acid bacteria isolated from donkey milk. Lett. Appl. Microbiol. 59:299-305. https: //doi.org/10.1111/lam.12275.

Clements, L. D., B. S. Miller, and U. N. Streips. 2002. Comparative growth analysis of the facultative anaerobes Bacillus subtilis, Bacillus licheniformis, and Escherichia coli. Syst. Appl. Microbiol. 25:284-286. https://doi.org/10.1078/0723-2020-00108.

Clinical Laboratory Standards Institute. 2012. Performance standards for antimicrobial susceptibility testing; twenty-second international supplement. Volume 32, Number 3. CLSI document M100-S22. Wayne, PA.

Cole, K., and J. Hogan. 2016. Short communication: Environmental mastitis pathogen counts in freestalls bedded with composted and fresh recycled manure solids. J. Dairy Sci. 99:1501-1505. https:// doi.org/10.3168/jds.2015-10238.

Coorevits, A., V. De Jonghe, J. Vandroemme, R. Reekmans, J. Heyrman, W. Messens, P. De Vos, and M. Heyndrickx. 2008. Comparative analysis of the diversity of aerobic spore-forming bacteria in raw milk from organic and conventional dairy farms. Syst. Appl. Microbiol. 31:126-140. https://doi.org/10.1016/j.syapm.2008.03 .002 .

De Jonghe, V., A. Coorevits, J. De Block, E. Van Coillie, K. Grijspeerdt, L. Herman, P. De Vos, and M. Heyndrickx. 2010. Toxinogenic and spoilage potential of aerobic spore-formers isolated from raw milk. Int. J. Food Microbiol. 136:318-325. https://doi.org/10 .1016/j.ijfoodmicro.2009.11.007.

Desfossés-Foucault, É., G. LaPointe, and D. Roy. 2014. Transcription profiling of interactions between Lactococcus lactis ssp. cremoris SK11 and Lactobacillus paracasei ATCC 334 during Cheddar cheese simulation. Int. J. Food Microbiol. 178:76-86. https://doi .org/10.1016/j.ijfoodmicro.2014.03.004.

Driehuis, F. 2013. Silage and the safety and quality of dairy foods: A review. Agric. Food Sci. 22:16-34. https://doi.org/10.23986/afsci .6699

Driehuis, F., E. Lucas-van den Bos, and M. H. J. Wells-Bennik. 2013. Risico's van het gebruik van gescheiden mest as beddinmateriaal voor de melkkwaliteit: sporen van Bacillus cereus en boterzuurbacteriën. (Risks of the use of cattle manure solids as bedding material for milk quality: Bacillus cereus and butyric acid bacteria). NIZO-Rapport E 2013/180 pp. NIZO Food Research BV, Ede, the Netherlands.

Driehuis, F., E. Lucas-van den Bos, and M. H. J. Wells-Bennik. 2014. Sporen van thermofiele aërobe sporenvormers in compost en andere beddingmaterialen bij melkveebedrijven met een vrijloop- of ligenboxenstal. (Spores of thermophilic aerobic sporeformers in compost and other bedding materials used by dairy farmers). NIZO-Rapport E 2014/045 pp. NIZO Food Research BV, Ede, the Netherlands.

Fournel, S., S. Godbout, P. Ruel, A. Fortin, K. Duquette-Lozeau, V. Létourneau, M. Généreux, J. Lemieux, D. Potvin, C. Côté, C. Duchaine, and D. Pellerin. 2019a. Production of recycled manure solids for use as bedding in Canadian dairy farms: II. Composting methods. J. Dairy Sci. 102:1847-1865. https://doi.org/10.3168/jds 2018-14967.

Fournel, S., S. Godbout, P. Ruel, A. Fortin, M. Généreux, C. Côté, C. Landry, and D. Pellerin. 2019b. Production of recycled manure solids for bedding in Canadian dairy farms: I. Solid-liquid separation. J. Dairy Sci. 102:1832-1846. https://doi.org/10.3168/jds .2018-14966.

Fox, P. F., T. P. Guinee, T. M. Cogan, and P. L. H. McSweeney. 2017a. Overview of cheese manufacture. Pages 11-25 in Fundamentals of Cheese Science. Springer US, Boston, MA.

Fox, P. F., T. P. Guinee, T. M. Cogan, and P. L. H. McSweeney. 2017b. Microbiology of cheese ripening. Pages 333-390 in Fundamentals of Cheese Science. Springer US, Boston, MA.

Franciosi, E., L. Settanni, A. Cavazza, and E. Poznanski. 2009. Biodiversity and technological potential of wild lactic acid bacteria from raw cows' milk. Int. Dairy J. 19:3-11. https://doi.org/10.1016/j .idairyj.2008.07.008.

Gelsomino, R., M. Vancanneyt, T. M. Cogan, S. Condon, and J. Swings. 2002. Source of enterococci in a farmhouse raw-milk cheese. Appl. Environ. Microbiol. 68:3560-3565. https://doi.org/ 10.1128/aem.68.7.3560-3565.2002.

Giraffa, G. 2003. Functionality of enterococci in dairy products. Int. J. Food Microbiol. 88:215-222. https://doi.org/10.1016/s0168 -1605(03)00183-1.

Gobbetti, M., R. Di Cagno, M. Calasso, E. Neviani, P. F. Fox, and M. De Angelis. 2018. Drivers that establish and assembly the lactic acid bacteria biota in cheeses. Trends Food Sci. Technol. 78:244254. https://doi.org/10.1016/j.tifs.2018.06.010.

Gómez-Torres, N., S. Garde, Á. Peirotén, and M. Ávila. 2015. Impact of Clostridium spp. on cheese characteristics: Microbiology, color, formation of volatile compounds and off-flavors. Food Control 56:186-194. https://doi.org/10.1016/j.foodcont.2015.03.025.

Hendriks, J., A. Oubrie, J. Castresana, A. Urbani, S. Gemeinhardt, and M. Saraste. 2000. Nitric oxide reductases in bacteria. Biochim. Biophys. Acta Bioenerg. 1459:266-273. https://doi.org/10.1016/ S0005-2728(00)00161-4.

Lahti, L., S. Shetty, et al. 2017. Tools for microbiome analysis in R Version 1.5.23. http://microbiome.github.com/microbiome.

Lawrence, R., J. Gilles, L. Creamer, V. L. Crow, H. A. Heap, C. G. Honoré, K. A. Johnston, and P. K. Samal. 2004. Cheddar cheese and related dry-salted cheese varieties. Pages 71-102 in Cheese: Chemistry, Physics and Microbiology. P. F. Fox, P. L. H. McSweeney, T. M. Cogan, and T. P. Guinee, ed. Elsevier.

Layton, B. A., S. P. Walters, L. H. Lam, and A. B. Boehm. 2010. Enterococcus species distribution among human and animal hosts using multiplex PCR. J. Appl. Microbiol. 109:539-547. https://doi .org/10.1111/j.1365-2672.2010.04675.x.

Leach, K. A., S. C. Archer, J. E. Breen, M. J. Green, I. C. Ohnstad, S. Tuer, and A. J. Bradley. 2015. Recycling manure as cow bedding: Potential benefits and risks for UK dairy farms. Vet. J. 206:123130. https://doi.org/10.1016/j.tvjl.2015.08.013.

Licitra, G., J. C. Ogier, S. Parayre, C. Pediliggieri, T. M. Carnemolla, H. Falentin, M. N. Madec, S. Carpino, and S. Lortal. 2007. Variability of bacterial biofilms of the "tina" wood vats used in the ragusano cheese-making process. Appl. Environ. Microbiol. 73:6980-6987. https://doi.org/10.1128/AEM.00835-07.

Lick, S., M. Keller, W. Bockelmann, and J. Heller. 1996. Rapid identification of Streptococcus thermophilus by primer-specific PCR amplification based on its lacZ gene. Syst. Appl. Microbiol. 19:74-77. https://doi.org/10.1016/S0723-2020(96)80012-9.

Lis, D. O., J. Z. Pacha, and R. L. Górny. 2008. Bacterial contamination of the air in farmhouses. Indoor Air 8:17-22.

Mao, S., R. Zhang, D. Wang, and W. Zhu. 2012. The diversity of the fecal bacterial community and its relationship with the concentration of volatile fatty acids in the feces during subacute rumen acidosis in dairy cows. BMC Vet. Res. 8:237. https://doi.org/10 .1186/1746-6148-8-237.

McMurdie, P. J., and S. Holmes. 2013. phyloseq: An R Package for reproducible interactive analysis and graphics of microbiome census data. PLoS One 8:e61217. https://doi.org/10.1371/journal.pone .0061217.

Miller, R. A., D. J. Kent, M. J. Watterson, K. J. Boor, N. H. Martin, and M. Wiedmann. 2015. Spore populations among bulk tank raw milk and dairy powders are significantly different. J. Dairy Sci. 98:8492-8504. https://doi.org/10.3168/jds.2015-9943.

Nomura, T., Y. Hashimoto, J. Kurushima, H. Hirakawa, K. Tanimoto, B. Zheng, G. Ruan, F. Xue, J. Liu, J. Hisatsune, M. Sugai, and H. Tomita. 2018. New colony multiplex PCR assays for the detection and discrimination of vancomycin-resistant enterococcal species. J. Microbiol. Methods 145:69-72. https://doi.org/10.1016/j.mimet 2017.12.013.

O'Driscoll, T., and C. W. Crank. 2015. Vancomycin-resistant enterococcal infections: Epidemiology, clinical manifestations, and optimal management. Infect. Drug Resist. 8:217-230. https://doi.org/ 10.2147/IDR.S54125. 
Parks, D. H., G. W. Tyson, P. Hugenholtz, and R. G. Beiko. 2014. STAMP: Statistical analysis of taxonomic and functional profiles. Bioinformatics 30:3123-3124. https://doi.org/10.1093/ bioinformatics/btu494.

Petersen, S. O., S. G. Sommer, F. Béline, C. Burton, J. Dach, J. Y. Dourmad, A. Leip, T. Misselbrook, F. Nicholson, H. D. Poulsen, G. Provolo, P. Sørensen, B. Vinnerås, A. Weiske, M.-P. Bernal, R. Böhm, C. Juhász, and R. Mihelic. 2007. Recycling of livestock manure in a whole-farm perspective. Livest. Sci. 112:180-191. https:/ /doi.org/10.1016/j.livsci.2007.09.001.

Quigley, L., O. O'Sullivan, C. Stanton, T. P. Beresford, R. P. Ross, G. F. Fitzgerald, and P. D. Cotter. 2013. The complex microbiota of raw milk. FEMS Microbiol. Rev. 37:664-698. https://doi.org/10 $.1111 / 1574-6976.12030$

R Core Team. 2013. R: A language and environment for statistical computing. R Foundation for Statistical Computing, Vienna, Austria. http://www.R-project.org/.

Rasolofo, E. A., D. St-Gelais, G. LaPointe, and D. Roy. 2010. Molecular analysis of bacterial population structure and dynamics during cold storage of untreated and treated milk. Int. J. Food Microbiol. 138:108-118. https://doi.org/10.1016/j.ijfoodmicro.2010.01.008.

Renye, J. A., G. A. Somkuti, D. L. Van Hekken, and V. M. Guerrero Prieto. 2011. Short communication: Characterization of microflora in Mexican Chihuahua cheese. J. Dairy Sci. 94:3311-3315. https:/ /doi.org/10.3168/jds.2011-4177.

Rey, M. W., P. Ramaiya, B. A. Nelson, S. D. Brody-Karpin, E.J. Zaretsky, M. Tang, A. de Leon, H. Xiang, V. Gusti, I.G. Clausen, P. B. Olsen, M.D. Rasmussen, J. T. Andersen, P. L. Jørgensen, T. S. Larsen, A. Sorokin, A. Bolotin, A. Lapidus, N. Galleron, S.D. Ehrlich, and R. M. Berka. 2004. Complete genome sequence of the industrial bacterium Bacillus licheniformis and comparisons with closely related Bacillus species. Genome Biol. 5:r77. https://doi .org/10.1186/gb-2004-5-10-r77.

Ricciardi, A., A. Guidone, R. G. Ianniello, S. Cioffi, M. Aponte, D. Pavlidis, E. Tsakalidou, T. Zotta, and E. Parente. 2015. A survey of non-starter lactic acid bacteria in traditional cheeses: Culture dependent identification and survival to simulated gastrointestinal transit. Int. Dairy J. 43:42-50. https://doi.org/10.1016/j.idairyj .2014.11.006.

Rowbotham, R. F., and P. L. Ruegg. 2015. Association of bedding types with management practices and indicators of milk quality on larger Wisconsin dairy farms. J. Dairy Sci. 98:7865-7885. https:// doi.org/10.3168/jds.2015-9866.
Savard, P., B. Lamarche, M.-E. Paradis, H. Thiboutot, É. Laurin, and D. Roy. 2011. Impact of Bifidobacterium animalis ssp. lactis BB-12 and, Lactobacillus acidophilus LA-5-containing yoghurt, on fecal bacterial counts of healthy adults. Int. J. Food Microbiol. 149:50-57. https://doi.org/10.1016/j.ijfoodmicro.2010.12.026.

Shahbal, S., D. Hemme, and M. Desmazeaud. 1991. High cell wallassociated proteinase activity of some Streptococcus thermophilus strains (H-strains) correlated with a high acidification rate in milk Lait 71:351-357. https://doi.org/10.1051/lait:1991327.

Singh, T. K., M. A. Drake, and K. R. Cadwallader. 2003. Flavor of Cheddar cheese: A chemical and sensory perspective. Compr. Rev. Food Sci. Food Saf. 2:166-189. https://doi.org/10.1111/j.1541 $-4337.2003 . t b 00021 . x$.

Skeie, S. B., M. Håland, I. M. Thorsen, J. Narvhus, and D. Porcellato. 2019. Bulk tank raw milk microbiota differs within and between farms: A moving goalpost challenging quality control. J. Dairy Sci. 102:1959-1971. https://doi.org/10.3168/jds.2017-14083.

Sorter, D. E., H. J. Kester, and J. S. Hogan. 2014. Short communication: Bacterial counts in recycled manure solids bedding replaced daily or deep packed in freestalls. J. Dairy Sci. 97:2965-2968. https://doi.org/10.3168/jds.2013-7814.

Vacheyrou, M., A.-C. Normand, P. Guyot, C. Cassagne, R. Piarroux, and Y. Bouton. 2011. Cultivable microbial communities in raw cow milk and potential transfers from stables of sixteen French farms. Int. J. Food Microbiol. 146:253-262. https://doi.org/10 .1016/j.ijfoodmicro.2011.02.033.

Yunita, D., and C. E. R. Dodd. 2018. Microbial community dynamics of a blue-veined raw milk cheese from the United Kingdom. J. Dairy Sci. 101:4923-4935. https://doi.org/10.3168/jds.2017-14104.

Zdanowicz, M., J. A. Shelford, C. B. Tucker, D. M. Weary, and M. A. G. von Keyserlingk. 2004. Bacterial populations on teat ends of dairy cows housed in free stalls and bedded with either sand or sawdust. J. Dairy Sci. 87:1694-1701. https://doi.org/10.3168/jds .S0022-0302(04)73322-6.

\section{ORCIDS}

Mérilie Gagnon @ https://orcid.org/0000-0002-0631-4946 Simon Dufour @ https://orcid.org/0000-0001-6418-0424 